\title{
Mesenchymal Stem Cells: The New Immunosuppressants?
}

\section{Varun Dhir}

\begin{abstract}
Mesenchymal stem cells are adult stem cells which can differentiate into cells of mesodermal lineage-osteoblasts, chondroblasts and adipocytes. They have an important property of immunosuppression which is mediated mainly through soluble mediators, like interleukin-1, transforming growth factor- $\beta$, nitric oxide, indoleamine 2,3 dioxegenase, etc. They have been shown to suppress both naïve and antigen experienced $T$ cells, lead to $\mathrm{T}$ cell arrest, and suppress Th1 and Th17 responses. They have also been shown to lead to development of tolerogenic dendritic cells, Th2 response and expansion of $\mathrm{T}$ regulatory cells. Importantly, MSCs are cells with a low immunogenic potential and hence have been used both in allogenic as well as xenogenic settings. MSCs have shown efficacy in suppressing the development of autoimmune disease in various animal models, like collagen induced arthritis, MRL-Ipr mice, EAE mice, etc. They have been used in small human studies, some of which have shown benefit like in systemic lupus erythematosus. Also, they have been used in graft-verus-host disease in humans with promising results. However, a single randomized controlled trial has been done and, thus, their current status remains investigational. It is hoped that they may become part of the armamentarium to control and abberant or excessive immune reponse.
\end{abstract}

Keywords: Mesenchymal stem cells, Immunosuppression, Autoimmune disease, Adult stem cells.

Key messages: (1) Mesenchymal stem cells (MSCs) are adult stem cells that can differentiate only in one lineage (mesodermal). (2) They were first discovered in the bone marrow and this remains a common source, followed by adipose tissue. There are other sources: Synovial fluid, umbilical cord blood, amniotic fluid, placenta, fetal liver. (3) MSCs are immunosuppressive, the mechanism of which is not fully elucidated, but involves action on other cells mainly through soluble mediators, like TGF $\beta$, IDO, IL-1, NO, etc. (4) MSCs have shown efficacy in various animal models of autoimmune diseases. There have been small human studies, some of which showed benefit, however, a single randomized controlled trial has been done. (5) MSCs may have a role in autoimmune diseases refractory to treatment or as an add onto prevent treatment side effects.

How to cite this article: Dhir V. Mesenchymal Stem Cells: The New Immunosuppressants? J Postgrad Med Edu Res 2012;46(2):63-68.

\section{Source of support: Nil}

Conflict of interest: None declared

\section{INTRODUCTION}

Mesenchymal stem cells are a type of adult multipotent stem cells found in a variety of tissues. They express stromal markers but not hematopoietic markers. ${ }^{1}$ They can self renew and have lineage commitment, i.e. only differentiate into cells of the mesodermal lineage, i.e. bone, cartilage and fat. ${ }^{2-4}$ They are different from the embryonic stem cells which are totipotent, i.e. can differentiate into any tissue in the body, however, similar to other adult stem cells like hematopoietic stem cells, neural stem cells, intestinal stem cells that have limited differentiation capability. They were first discovered in the bone marrow as plastic adherent cells with a fibroblast like morphology. ${ }^{5-7}$ Initially called 'fibroblast precursors, the name mesenchymal stem cells was proposed later. ${ }^{8}$ MSCs found in the bone marrow (BMMSCs) comprise only about $0.001 \%$ of the bone marrow cells. Their main function in the bone marrow seems to be to provide the proper microenvironment to the hematopoietic stem cells. However, MSCs have also been isolated from other tissues as well, including the adipose tissue, skeletal muscle, umbilical cord, blood synovial fluid, dental tissues, palatine tonsil, amniotic fluid, Wharton's jelly, fetal liver, etc. ${ }^{9}$ The best characterized and usual source after the bone marrow is the adipose tissue. ${ }^{10}$ There seem to be subtle differences among the MSCs from various sites. The morphology can vary from fibroblastoid to giant fat cells, spindle-shaped cells to small round cells. ${ }^{11}$ Their immunosuppressive properties came to the fore, when they were found to suppress the alloantigen stimulated mixed lymphocyte reaction and also prevent the rejection of allogenic skin grafts with reduction in the production of proinflammatory cytokines TNF $\alpha$, and IFN. ${ }^{12}$ The international society for cell therapy has proposed a formal definition for mesenchymal stem cells. ${ }^{13}$ A cell is defined as MSC if it fulfills the following criteria:

- Plastic adherence

- Expresses CD 90, CD105 and CD73 but does not express CD 34, CD14, CD11b, CD79 and HLA DR by flowcytometry

- Capable of differentiating into osteoblasts, chondroblasts and adipocytes.

However, although not part of the criteria, MSCs also usually express Stro-1, CD44 and CD71. ${ }^{14}$ MSCs have low immunogenic potential and are 'Immune privileged' cells. They express low levels of MHC I, lack expression of MHC II and costimulatory molecules. ${ }^{14-16}$ Thus, they can be used allogenically and even xenogenically. This fact has led to much expectation and excitement in their use, as a major problem with other cell-based therapy has been the limitation of crossing the HLA barrier. 


\section{HOW DO MSCs MEDIATE IMMUNE MODULATION?}

MSCs nonspecifically suppress both naïve and antigen experienced CD4 and CD8 T cells. ${ }^{17}$ Activated T cells are arrested in the G0/G1 stage. They reduce IL-17 release by Th17 and IFN $\gamma$ release from Th1 effector cells, ${ }^{18,19}$ but increase IL-4 secretion by Th2 cells. ${ }^{20}$ MSCs lead to T regulatory cells (CD4 + CD25 + FoxP3+) expansion. ${ }^{18,20}$ They inhibit the differentiation and antibody production by B cells. ${ }^{21}$ They inhibit the immunostimulatory capacity of dendritic cells, leading to a more tolerogenic profile, and secretion of IL10. ${ }^{22,23}$ They inhibit activation and expansion of natural killer (NK) cells. ${ }^{24}$ They also reduce the levels of NK cell secreted cytokines, such as IFN, IL-10 and TNF. ${ }^{25}$

It has been proposed that a inflammatory environment leads to the development of suppressive 'powers' of MSC. Especially, the role of IFN $\gamma$ at an appropriate concentration seems important, which may lead to induction of IDO. ${ }^{26,27}$ Also, stimulation of particular toll like receptors (TLRs), like TLR3 might promote an immunosuppressive MSC. ${ }^{28}$ Immunosuppressive 'powers' of the MSC seem to be mainly related to soluble mediators. Various mediators have been found to be important (Table 1). These include interleukin-1 (IL-1), transforming growth factor (TGF $\beta$ ), hepatocyte growth factor (HGF), prostaglandin E2 (PGE2), indoleamine 2, 3 dioxygenase (IDO), heme oxygenase, nitric oxide (NO) and insulin like growth factor-binding proteins. ${ }^{29-33}$ Indoleamine 2, 3-dioxygenase (IDO) is an enzyme that catabolizes the essential amino acid tryptophan to kynurenine, and both the depletion of tryptophan and the accumulation of the toxic product have been proposed to be responsible for the immunosuppressive action. However, which of these molecules is the most important is unclear. There also seems to be a role of cell-to-cell contact by MSCs

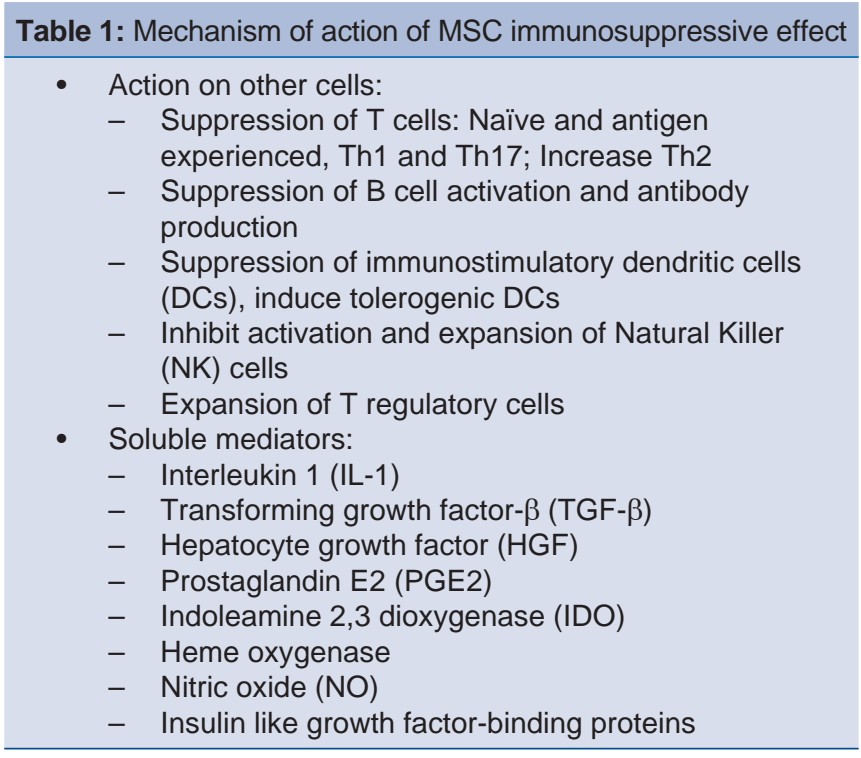

as the immunosuppressive effect is weaker in a transwell situation. ${ }^{34}$ The T reg expansion may be related to TGF $\beta$ secretion by MSCs. ${ }^{30,35}$ Although, the major effect is on the adaptive immunity, MSCs have been shown to inhibit production of reactive oxygen species (ROS) by neutrophils. ${ }^{36}$ The action of MSCs seems to be systemic; there is scant evidence that they actually home to the site of injury and actually transdifferentiate. There has been scant evidence of engraftment in the CNS in some studies in neurological disease, like MS and EAE animal model, particularly if directly injected. ${ }^{37}$

\section{USE OF MESENCHYMAL STEM CELLS IN AUTOIMMUNE DISEASE (ANIMAL MODELS)}

\section{Rheumatoid Arthritis}

Animal models: Amelioration of collagen-induced arthritis (CIA) has been shown with a single intraperitoneal injection of MSCs. ${ }^{38}$ That study found an increase in IL-10 and decrease in proinflammatory cytokines (Th1 and Th17) along with an increase in T-regs that could mediate this improvement. There was a reduction in proliferation of CD4 $\mathrm{T}$ cells in the draining lymph nodes on exposure to type II collagen. Also, earlier the injection, the lower was the arthritis score. Another study found daily intraperitoneal injections 5 days after onset of disease, reduced the incidence and severity of arthritis. ${ }^{39}$ Also, intra-articular MSCs were less effective than intraperitoneal injections. However, there have been negative studies as well that did not find an improvement (or even found an exacerbation) in CIA. ${ }^{40-42}$ One review reconciled these differences as due to the difference in protocols-route, source of MSCs, single vs multiple injections. ${ }^{43}$

Human: There is no published study on human studies in rheumatoid arthritis.

\section{Systemic Lupus Erythematosus}

Animal models: In the MRL-lpr mice model, clinical improvement and reduced anti-dsDNA titers have been found after allogenic MSC administration. ${ }^{44-46}$ There was an increase in T-regs and reduction in Th17 cells. There was also amelioration in the osteoporosis accompanying the disease. However, in the (NZBxNZW) F1 model, there was no clinical improvement or even exacerbation. ${ }^{47,48}$

Humans: In human SLE, there have been several studies. Two studies using intravenous infusion of allogenic BMMSC from family members found improvement in disease score, proteinuria and decreased requirement for immunosuppression on follow-up of around 1.5 years after MSC administration. ${ }^{45,49}$ Another study showed similar 
improvements with umbilical cord derived MSCs. ${ }^{50}$ There was an increase in the CD4+FoxP3+Treg at 3 and 6 months, accompanied by an increase in the levels of TGF and IL-10. ${ }^{45}$ However, a shorter study did not find any improvement. ${ }^{51}$

\section{Systemic Sclerosis (Scleroderma)}

A single case report found a decreased skin score in a patient given MSCs from haploidential allogenic donor 6 months after administration. ${ }^{52}$

\section{Multiple Sclerosis}

Animal model: In experimental allergic encephalomyelitis (EAE), intravenous infusion of syngenic MSCs was found to ameliorate the disease when administered at onset or peak of the disease but not in the chronic progressive phase. ${ }^{53}$ There was an improvement in the demyelination and $\mathrm{T}$ cell infiltration in the CNS. There was engraftment of the MSCs in the secondary lymphoid organs, inducing T cell tolerance, to the immunizing antigen myelin oligodendrocyte glycoprotein. There have been several other studies that have shown improvement in clinical scores using MSCs. ${ }^{54,55}$ A later study using adipose tissue MSCs showed ability to improve even established disease. ${ }^{56}$

Humans: In multiple sclerosis, three small studies (7-15 patients) using autologous MSCs have been done with administration of MSCs intrathecally (in one additional intravenous). ${ }^{57-59}$ These found either no or inconsistent improvement (i.e. clinicoradiological discordance in improvement). The major adverse effect was headache with few developing aseptic meningitis.

\section{Amyotrophic Lateral Sclerosis}

In ALS, three studies of few patients (9-19 patients) using autologous MSCs have been done. ${ }^{57,60}$ There was no improvement in disease.

\section{Myasthenia Gravis}

Animal model: Use in the experimental autoimmune myasthenia gravis (EAMG) model led to lower titers of acetyl cholinesterase antibodies and improvement in clinical scores. ${ }^{61}$

\section{Inflammatory Bowel Disease}

Animal model: In trinitrobenzene sulfonic acid induced colitis, there was improvement on systemic administration of MSCs. In a FoxP3 deficient model which leads to generalized autoimmunity including bowel inflammation, there as an improvement in ileum inflammation on MSC administration. ${ }^{62}$

In Crohn's disease, few phase 1 studies have been done.

\section{Type 1 Diabetes Mellitus}

Animal model: In the STZ induced diabetes model led to higher insulin secretion and larger numbers and size of remaining islets. ${ }^{63}$

\section{USE OF MSC IN NONAUTOIMMUNE IMMUNE- MEDIATED DISEASE}

\section{Graft versus Host Disease (GVHD)}

Animal models: A single infusion of MSCs at the time of bone marrow transplant in mice did not prevent GVHD. ${ }^{64}$ However, multiple doses could prevent it. ${ }^{65}$ Another study found administration of MSCs only in a certain time interval, i.e. from day +2 to +20 leads to an increase in the survival times of recipient mice, which may be related to high levels of IFN $\gamma{ }^{66,67}$

Humans: First in a single case, and then later in a study on 55 patients, it was shown that MSCs could improve GVHD and lead to better survival. ${ }^{68,69}$ However, a study where MSCs were given before hematopoietic stem cell transplant (i.e. before GVHD was there) showed no benefit. ${ }^{70}$

\section{Organ Transplantation}

Animal models: One of the first animal experiments regarding MSC involved baboons with allogenic mismatched skin transplants in whom infusion of MSCs led to longer survival of graft. ${ }^{12}$ Subsequent experiments involved administration of donor-derived mesenchymal stem cells which prolonged survival of rat cardiac allograft. ${ }^{71}$ MSCs have also been shown to synergize with immunosuppressant's to improve outcome of allografts — cardiac and solid organ. ${ }^{72}$ A recent randomized controlled study in renal transplant recipients, in those who received autologus MSCs along with calcineurin inhibitors had a lower rate of biopsy confirmed acute rejection at 6 months, compared to those receiving calcineurin inhibitors with anti-IL2 therapy. The MSC treated patients also had near half reduction in opportunistic infections. However, survival and graft survival were not different at 30 months. $^{73}$

\section{Acute Lung Injury (ALI)}

Animal models: In C57 BL/6 mice in whom ALI was induced with high dose of intra-alveolar endotoxin, administration of MSC via the intratracheal route 4 hours later led to reduction in injury compared to saline control. There was a reduction in pulmonary edema, 
pro-inflammatory cytokines and increase in antiinflammatory cytokines, like IL-10 and IL-13. There was also an improvement in survival. ${ }^{74}$ MSCs also reduced mortality in E. coli induced ALI. Neonatal experimental models have shown improvement in lung damage in hyperoxic neonatal lung injury models. ${ }^{75}$

\section{CONCLUSION}

Mesenchymal stem cells are an evolving therapy as immunosuppressive agents that may find to use in autoimmune diseases, graft-versus-host disease, organ transplantation and other immune mediated injuries, like ALI. They have a distinct advantage of low immunogenicity that permits allogenic and even xenogenic use. However, although they have shown efficacy in animal models, the human studies have been small and nonrandomized-thus as of now they it remains to be seen whether they will make it form the bench to the bedside.

\section{REFERENCES}

1. Horwitz EM, Le Blanc K, Dominici M, Mueller I, SlaperCortenbach I, Marini FC, et al. Clarification of the nomenclature for MSC: The International Society for Cellular Therapy Position Statement. Cytotherapy 2005;7(5):393-95.

2. Bruder SP, Jaiswal N, Haynesworth SE. Growth kinetics, selfrenewal, and the osteogenic potential of purified human mesenchymal stem cells during extensive subcultivation and following cryopreservation. J Cell Biochem 1997 Feb;64(2): 278-94.

3. Haynesworth SE, Goshima J, Goldberg VM, Caplan AI. Characterization of cells with osteogenic potential from human marrow. Bone 1992;13(1):81-88.

4. Pittenger MF, Mackay AM, Beck SC, Jaiswal RK, Douglas R, Mosca JD, et al. Multilineage potential of adult human mesenchymal stem cells. Science 1999 Apr 2;284(5411):143-47.

5. Afanasyev SA, Rogovskaya EV, Sviridov IN, Falaleeva LP, Shakhov VP, Popov SV, et al. Effect of transplantation of bone marrow cells on morphology of rat myocardium after cryodestruction. Bull Exp Biol Med 2009 Apr;147(4):517-20.

6. Friedenstein AJ, Deriglasova UF, Kulagina NN, Panasuk AF, Rudakowa SF, Luria EA, et al. Precursors for fibroblasts in different population of hematopoietic cells as detected by the in vitro colony assay method. Exp Hematol 1974;2(2):83-92.

7. Friedenstein AJ, Piatetzky S, II, Petrakova KV. Osteogenesis in transplants of bone marrow cells. J Embryol Exp Morphol 1966 Dec;16(3):381-90.

8. Caplan AI. Mesenchymal stem cells. J Orthop Res 1991 Sep; 9(5):641-50.

9. Chen PM, Yen ML, Liu KJ, Sytwu HK, Yen BL. Immunomodulatory properties of human adult and fetal multipotent mesenchymal stem cells. J Biomed Sci 2011;18:49.

10. Zuk PA, Zhu M, Mizuno H, Huang J, Futrell JW, Katz AJ, et al. Multilineage cells from human adipose tissue: Implications for cell-based therapies. Tissue Eng 2001 Apr;7(2):211-28.

11. Pevsner-Fischer M, Levin S, Zipori D. The origins of mesenchymal stromal cell heterogeneity. Stem Cell Rev 2011 Sep;7(3):560-68.
12. Bartholomew A, Sturgeon C, Siatskas M, Ferrer K, McIntosh K, Patil S, et al. Mesenchymal stem cells suppress lymphocyte proliferation in vitro and prolong skin graft survival in vivo. Exp Hematol 2002 Jan;30(1):42-48.

13. Dominici M, Le Blanc K, Mueller I, Slaper-Cortenbach I, Marini F, Krause D, et al. Minimal criteria for defining multipotent mesenchymal stromal cells. The International Society for Cellular Therapy position statement. Cytotherapy 2006;8(4):315-17.

14. Chamberlain G, Fox J, Ashton B, Middleton J. Concise review: Mesenchymal stem cells: Their phenotype, differentiation capacity, immunological features, and potential for homing. Stem Cells 2007 Nov;25(11):2739-49.

15. Le Blanc K, Tammik C, Rosendahl K, Zetterberg E, Ringden O. HLA expression and immunologic properties of differentiated and undifferentiated mesenchymal stem cells. Exp Hematol 2003 Oct;31(10):890-96.

16. Majumdar MK, Keane-Moore M, Buyaner D, Hardy WB, Moorman MA, McIntosh KR, et al. Characterization and functionality of cell surface molecules on human mesenchymal stem cells. J Biomed Sci 2003 Mar-Apr;10(2):228-41.

17. Krampera M, Glennie S, Dyson J, Scott D, Laylor R, Simpson E, et al. Bone marrow mesenchymal stem cells inhibit the response of naive and memory antigen-specific $\mathrm{T}$ cells to their cognate peptide. Blood 2003 May 1;101(9):3722-29.

18. Ghannam S, Pene J, Torcy-Moquet G, Jorgensen C, Yssel H. Mesenchymal stem cells inhibit human Th17 cell differentiation and function and induce a $\mathrm{T}$ regulatory cell phenotype. J Immunol 2010 July 1;185(1):302-12.

19. Glennie S, Soeiro I, Dyson PJ, Lam EW, Dazzi F. Bone marrow mesenchymal stem cells induce division arrest anergy of activated T cells. Blood 2005 Apr 1;105(7):2821-27.

20. Aggarwal S, Pittenger MF. Human mesenchymal stem cells modulate allogeneic immune cell responses. Blood 2005 Feb15; 105(4):1815-22.

21. Corcione A, Benvenuto F, Ferretti E, Giunti D, Cappiello V, Cazzanti F, et al. Human mesenchymal stem cells modulate B-cell functions. Blood 2006 Jan 1;107(1):367-72.

22. Jiang XX, Zhang Y, Liu B, Zhang SX, Wu Y, Yu XD, et al. Human mesenchymal stem cells inhibit differentiation and function of monocyte-derived dendritic cells. Blood 2005 May 15;105(10):4120-26.

23. Spaggiari GM, Abdelrazik H, Becchetti F, Moretta L. MSCs inhibit monocyte-derived DC maturation and function by selectively interfering with the generation of immature DCs: Central role of MSC-derived prostaglandin E2. Blood 2009 June 25;113(26):6576-83.

24. Spaggiari GM, Capobianco A, Becchetti S, Mingari MC, Moretta L. Mesenchymal stem cell-natural killer cell interactions: Evidence that activated NK cells are capable of killing MSCs, whereas MSCs can inhibit IL-2-induced NK-cell proliferation. Blood 2006 Feb 15;107(4):1484-90.

25. Sotiropoulou PA, Perez SA, Gritzapis AD, Baxevanis CN, Papamichail M. Interactions between human mesenchymal stem cells and natural killer cells. Stem Cells 2006 Jan;24(1): 74-85.

26. Dazzi F, Krampera M. Mesenchymal stem cells and autoimmune diseases. Best Pract Res Clin Haematol 2011 Mar;24(1):49-57.

27. Krampera M, Cosmi L, Angeli R, Pasini A, Liotta F, Andreini A, et al. Role for interferon-gamma in the immunomodulatory activity of human bone marrow mesenchymal stem cells. Stem Cells 2006 Feb;24(2):386-98. 
28. Waterman RS, Tomchuck SL, Henkle SL, Betancourt AM. A new mesenchymal stem cell (MSC) paradigm: Polarization into a pro-inflammatory MSC1 or an immunosuppressive MSC2 phenotype. PloS one 2010;5(4):e10088.

29. Chabannes D, Hill M, Merieau E, Rossignol J, Brion R, Soulillou JP, et al. A role for heme oxygenase-1 in the immunosuppressive effect of adult rat and human mesenchymal stem cells. Blood 2007 Nov 15;110(10):3691-94.

30. English K, Ryan JM, Tobin L, Murphy MJ, Barry FP, Mahon BP. Cell contact, prostaglandin E(2) and transforming growth factor beta 1 play non-redundant roles in human mesenchymal stem cell induction of CD4+CD25(High) forkhead box P3+ regulatory T cells. Clin Exp Immunol 2009 Apr;156(1): 149-60.

31. Groh ME, Maitra B, Szekely E, Koc ON. Human mesenchymal stem cells require monocyte-mediated activation to suppress alloreactive T cells. Exp Hematol 2005 Aug;33(8):928-34.

32. Meisel R, Zibert A, Laryea M, Gobel U, Daubener W, Dilloo D. Human bone marrow stromal cells inhibit allogeneic T-cell responses by indoleamine 2,3-dioxygenase-mediated tryptophan degradation. Blood 2004 June 15;103(12):4619-21.

33. Sato K, Ozaki K, Oh I, Meguro A, Hatanaka K, Nagai T, et al. Nitric oxide plays a critical role in suppression of T-cell proliferation by mesenchymal stem cells. Blood 2007 Jan 1; 109(1):228-34.

34. Xue Q, Luan XY, Gu YZ, Wu HY, Zhang GB, Yu GH, et al. The negative co-signaling molecule b7-h4 is expressed by human bone marrow-derived mesenchymal stem cells and mediates its T-cell modulatory activity Stem Cells Dev 2010 Jan;19(1): 27-38.

35. Prevosto C, Zancolli M, Canevali P, Zocchi MR, Poggi A. Generation of CD4+ or CD8+ regulatory T cells upon mesenchymal stem cell-lymphocyte interaction. Haematologica 2007 Jul;92(7):881-88.

36. Morandi F, Raffaghello L, Bianchi G, Meloni F, Salis A, Millo E, et al. Immunogenicity of human mesenchymal stem cells in HLA-class I-restricted T-cell responses against viral or tumor-associated antigens. Stem Cells 2008 May;26(5): 1275-87.

37. Kassis I, Grigoriadis N, Gowda-Kurkalli B, Mizrachi-Kol R, Ben-Hur T, Slavin S, et al. Neuroprotection and immunomodulation with mesenchymal stem cells in chronic experimental autoimmune encephalomyelitis. Arch Neurol 2008 Jun;65(6):753-61.

38. Augello A, Tasso R, Negrini SM, Cancedda R, Pennesi G. Cell therapy using allogeneic bone marrow mesenchymal stem cells prevents tissue damage in collagen-induced arthritis. Arthritis Rheum 2007 Apr;56(4):1175-86.

39. Gonzalez MA, Gonzalez-Rey E, Rico L, Buscher D, Delgado M. Treatment of experimental arthritis by inducing immune tolerance with human adipose-derived mesenchymal stem cells. Arthritis Rheum 2009 Apr;60(4):1006-19.

40. Chen B, Hu J, Liao L, Sun Z, Han Q, Song Z, et al. Flk-1+ mesenchymal stem cells aggravate collagen-induced arthritis by up-regulating interleukin-6. Clin Exp Immunol 2010 Mar; 159(3):292-302.

41. Djouad F, Fritz V, Apparailly F, Louis-Plence P, Bony C, Sany J, et al. Reversal of the immunosuppressive properties of mesenchymal stem cells by tumor necrosis factor alpha in collagen-induced arthritis. Arthritis Rheum 2005 May;52(5): 1595-603.
42. Schurgers E, Kelchtermans H, Mitera T, Geboes L, Matthys P. Discrepancy between the in vitro and in vivo effects of murine mesenchymal stem cells on T-cell proliferation and collageninduced arthritis. Arthritis Res Ther 2010;12(1):R31.

43. MacDonald GI, Augello A, De Bari C. Role of mesenchymal stem cells in reestablishing immunologic tolerance in autoimmune rheumatic diseases. Arthritis Rheum 2011 Sep;63(9): 2547-57.

44. Gu Z, Akiyama K, Ma X, Zhang H, Feng X, Yao G, et al. Transplantation of umbilical cord mesenchymal stem cells alleviates lupus nephritis in MRL/lpr mice. Lupus 2010 Nov; 19(13):1502-14

45. Sun L, Akiyama K, Zhang H, Yamaza T, Hou Y, Zhao S, et al. Mesenchymal stem cell transplantation reverses multiorgan dysfunction in systemic lupus erythematosus mice and humans. Stem Cells 2009 Jun;27(6):1421-32.

46. Zhou K, Zhang H, Jin O, Feng X, Yao G, Hou Y, et al. Transplantation of human bone marrow mesenchymal stem cell ameliorates the autoimmune pathogenesis in MRL/lpr mice. Cell Mol Immunol 2008 Dec;5(6):417-24.

47. Schena F, Gambini C, Gregorio A, Mosconi M, Reverberi D, Gattorno M, et al. Interferon-gamma-dependent inhibition of B cell activation by bone marrow-derived mesenchymal stem cells in a murine model of systemic lupus erythematosus. Arthritis Rheum 2010 Sep;62(9):2776-86.

48. Youd M, Blickarz C, Woodworth L, Touzjian T, Edling A, Tedstone J, et al. Allogeneic mesenchymal stem cells do not protect NZBxNZW F1 mice from developing lupus disease. Clin Exp Immunol $2010 \mathrm{Jul}$ 1;161(1):176-86.

49. Liang J, Zhang H, Hua B, Wang H, Lu L, Shi S, et al. Allogenic mesenchymal stem cells transplantation in refractory systemic lupus erythematosus: A pilot clinical study. Ann Rheum Dis 2010 Aug;69(8):1423-29.

50. Sun L, Wang D, Liang J, Zhang H, Feng X, Wang H, et al. Umbilical cord mesenchymal stem cell transplantation in severe and refractory systemic lupus erythematosus. Arthritis Rheum 2010 Aug;62(8):2467-75.

51. Carrion F, Nova E, Ruiz C, Diaz F, Inostroza C, Rojo D, et al. Autologous mesenchymal stem cell treatment increased $\mathrm{T}$ regulatory cells with no effect on disease activity in two systemic lupus erythematosus patients. Lupus 2010 Mar;19(3):317-22.

52. Christopeit M, Schendel M, Foll J, Muller LP, Keysser G, Behre G. Marked improvement of severe progressive systemic sclerosis after transplantation of mesenchymal stem cells from an allogeneic haploidentical-related donor mediated by ligation of CD137L. Leukemia 2008 May;22(5):1062-64.

53. Zappia E, Casazza S, Pedemonte E, Benvenuto F, Bonanni I, Gerdoni E, et al. Mesenchymal stem cells ameliorate experimental autoimmune encephalomyelitis inducing T-cell anergy. Blood 2005 Sep 1;106(5):1755-61.

54. Gordon D, Pavlovska G, Glover CP, Uney JB, Wraith D, Scolding NJ. Human mesenchymal stem cells abrogate experimental allergic encephalomyelitis after intraperitoneal injection, and with sparse CNS infiltration. Neurosci Lett 2008 Dec 19;448(1):71-73.

55. Rafei M, Campeau PM, Aguilar-Mahecha A, Buchanan M, Williams P, Birman E, et al. Mesenchymal stromal cells ameliorate experimental autoimmune encephalomyelitis by inhibiting CD4 Th17 T cells in a CC chemokine ligand 2-dependent manner. J Immunol 2009 May 15;182(10):59946002. 
56. Constantin G, Marconi S, Rossi B, Angiari S, Calderan L, Anghileri E, et al. Adipose-derived mesenchymal stem cells ameliorate chronic experimental autoimmune encephalomyelitis. Stem Cells 2009 Oct;27(10):2624-35.

57. Karussis D, Karageorgiou C, Vaknin-Dembinsky A, GowdaKurkalli B, Gomori JM, Kassis I, et al. Safety and immunological effects of mesenchymal stem cell transplantation in patients with multiple sclerosis and amyotrophic lateral sclerosis. Arch Neurol 2010 Oct;67(10):1187-94.

58. Mohyeddin Bonab M, Yazdanbakhsh S, Lotfi J, Alimoghaddom K, Talebian F, Hooshmand F, et al. Does mesenchymal stem cell therapy help multiple sclerosis patients? Report of a pilot study. Iran J Immunol 2007 Mar;4(1):50-57.

59. Yamout B, Hourani R, Salti H, Barada W, El-Hajj T, Al-Kutoubi A, et al. Bone marrow mesenchymal stem cell transplantation in patients with multiple sclerosis: A pilot study. J Neuroimmunol (Clinical Trial, Phase I Comparative Study Research Support, Non-US Govt) 2010 Oct 8;227(1-2): 185-89.

60. Mazzini L, Mareschi K, Ferrero I, Vassallo E, Oliveri G, Nasuelli N, et al. Stem cell treatment in amyotrophic lateral sclerosis. J Neurol Sci 2008 Feb 15;265(1-2):78-83.

61. Kong QF, Sun B, Bai SS, Zhai DX, Wang GY, Liu YM, et al. Administration of bone marrow stromal cells ameliorates experimental autoimmune myasthenia gravis by altering the balance of Th1/Th2/Th17/Treg cell subsets through the secretion of TGF-beta. J Neuroimmunol 2009 Feb 15;207(1-2):83-91.

62. Parekkadan B, Tilles AW, Yarmush ML. Bone marrow-derived mesenchymal stem cells ameliorate autoimmune enteropathy independently of regulatory T cells. Stem Cells 2008 Jul;26(7): 1913-19.

63. Vija L, Farge D, Gautier JF, Vexiau P, Dumitrache C, Bourgarit A, et al. Mesenchymal stem cells: Stem cell therapy perspectives for type 1 diabetes. Diabetes Metab 2009 Apr;35(2): 85-93.

64. Sudres M, Norol F, Trenado A, Gregoire S, Charlotte F, Levacher B, et al. Bone marrow mesenchymal stem cells suppress lymphocyte proliferation in vitro but fail to prevent graft-versus-host disease in mice. J Immunol 2006 Jun 15; 176(12):7761-67.

65. Tisato V, Naresh K, Girdlestone J, Navarrete C, Dazzi F. Mesenchymal stem cells of cord blood origin are effective at preventing but not treating graft-versus-host disease. Leukemia 2007 Sep;21(9):1992-99.

66. Aksu AE, Horibe E, Sacks J, Ikeguchi R, Breitinger J, Scozio M, et al. Co-infusion of donor bone marrow with host mesenchymal stem cells treats GVHD and promotes vascularized skin allograft survival in rats. Clin Immunol 2008 Jun;127(3):348-58.
67. Yanez R, Lamana ML, Garcia-Castro J, Colmenero I, Ramirez M, Bueren JA. Adipose tissue-derived mesenchymal stem cells have in vivo immunosuppressive properties applicable for the control of the graft-versus-host disease. Stem Cells 2006 Nov;24(11): 2582-91.

68. Le Blanc K, Frassoni F, Ball L, Locatelli F, Roelofs H, Lewis I, et al. Mesenchymal stem cells for treatment of steroid-resistant, severe, acute graft-versus-host disease: A phase II study. Lancet 2008 May 10;371(9624):1579-86.

69. Le Blanc K, Rasmusson I, Sundberg B, Gotherstrom C, Hassan M, Uzunel M, et al. Treatment of severe acute graftversus-host disease with third party haploidentical mesenchymal stem cells. Lancet 2004 May 1;363(9419):1439-41.

70. Lazarus HM, Koc ON, Devine SM, Curtin P, Maziarz RT, Holland HK, et al. Cotransplantation of HLA-identical sibling culture-expanded mesenchymal stem cells and hematopoietic stem cells in hematologic malignancy patients. Biol Blood Marrow Transplant 2005 May;11(5):389-98.

71. Zhou HP, Yi DH, Yu SQ, Sun GC, Cui Q, Zhu HL, et al. Administration of donor-derived mesenchymal stem cells can prolong the survival of rat cardiac allograft. Transplant Proc 2006 Nov;38(9):3046-51.

72. Ge W, Jiang J, Baroja ML, Arp J, Zassoko R, Liu W, et al. Infusion of mesenchymal stem cells and rapamycin synergize to attenuate alloimmune responses and promote cardiac allograft tolerance. Am J Transplant 2009 Aug;9(8):1760-72.

73. Tan J, Wu W, Xu X, Liao L, Zheng F, Messinger S, et al. Induction therapy with autologous mesenchymal stem cells in living-related kidney transplants: A randomized controlled trial. JAMA 2012 Mar 21;307(11):1169-77.

74. Gupta N, Su X, Popov B, Lee JW, Serikov V, Matthay MA. Intrapulmonary delivery of bone marrow-derived mesenchymal stem cells improves survival and attenuates endotoxin-induced acute lung injury in mice. J Immunol 2007 Aug 1;179(3): 1855-63.

75. van Haaften T, Byrne R, Bonnet S, Rochefort GY, Akabutu J, Bouchentouf M, et al. Airway delivery of mesenchymal stem cells prevents arrested alveolar growth in neonatal lung injury in rats. Am J Respir Crit Care Med 2009 Dec 1;180(11): 1131-42.

\section{ABOUT THE AUTHOR}

\section{Varun Dhir}

Assistant Professor, Department of Internal Medicine, Postgraduate Institute of Medical Education and Research, Chandigarh-160012 India, Phone: +91-172-2756070, e-mail: varundhir@gmail.com 